\title{
Trephine stoma: Outcomes in a single center
}

\section{Trefin stoma: Tek merkez sonuçları}

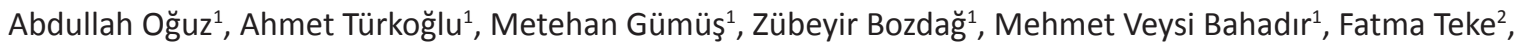
Hıdır Budak ${ }^{1}$, Abdullah Böyük ${ }^{1}$

\section{ABSTRACT}

Objective: Fecal diversion is often indicated in cases with fecal incontinence, Fournier's gangrene, anal fistula, and inoperable obstructive anorectal cancer. Trephine colostomy can be performed without necessitating laparotomy. We present our experience related to the outcome of trephine sigmoid colostomy.

Methods: The retrospective study included 14 patients who underwent trephine colostomy due to various conditions including Fournier's gangrene, inoperable anorectal cancer, recto-vaginal fistula, and benign stricture due to radiotherapy at our clinic between January 2010 and January 2015.

Results: Patients comprised 4 females and 10 males with a mean age of 52.07 years. The indications for stoma formation were Fournier's gangrene in 7 cases, inoperable anorectal cancer in 5 , rectovaginal fistula in 1 , and benign stricture due to radiotherapy in 1 case. Eight patients underwent surgery under regional anesthesia. All the patients underwent trephine loop sigmoid colostomy. One patient had second operation on the postoperative period due to colostomy prolapse. The temporary stomas were closed in 3 months. Mean length of hospital stay was 14 days.

Conclusion: Trephine stoma is a relatively simple, safe and rapid procedure and an effective alternative to colostomy formation without laparotomy indications. It can be performed under emergency or elective conditions with low morbidity. J Clin Exp Invest 2015; 6 (2): 87-90

\section{ÖZET}

Amaç: Saptırıcı stoma sıklıkla fekal inkontinans, Fournier gangreni, anorektal fistüller ve tıkayıc inoperable anorektal tümörler gibi durumlarda yapılır. Trefin stoma (TS) laparatomi yapılmaksızın yapılabilir. Biz bu çalışmada TS vakalarımızın sonuçlarıyla ilgili deneyimimizi paylaşmayı amaçladık.

Yöntemler: Bu çalışma 2010 ile 2015 yılları arasında kliniğimizde Fournier gangreni, inoperabl anorektal kanser, rektovajinal fistül ve radyoterapi nedeniyle oluşan benign striktür gibi çeşitli nedenlerle TS yapılan 14 hastanın verileri geriye doğru incelendi.

Bulgular: Hastalarımızın 10'u erkek, 4'ü kadın idi. Ortalama yaşları 52.07 yıl idi. Hastalarımızdan 7 tanesine Fournier gangreni, 5 tanesine inoperabl anorektal tümör, bir tanesine kompleks rekto-vajinal fistül ve bir tanesine de almış olduğu radyoterapiye bağlı gelişen tıkayıcı striktür nedeniyle TS yapıldı. Hastalarımızın 8 tanesine rejyonel anestezi uygulandı. Tüm hastalarımıza trefin loop sigmoid kolostomi uygulandı. Bir hastamız ostomi prolapsusu nedeniyle ikinci kez opere edildi. Geçici stomalar 3 ay sonra kapatıldı. Ortalama hastanede kalış süresi 14 gün idi.

Sonuç: TS görece basit, güvenli ve hızlı yapılan bir uygulama olup laparatomi endikasyonu olmayan hastalarda etkili alternatif bir yöntemdir. Düşük morbidite oranıyla acil ve elektif şartlarda uygulanabilir.

Anahtar kelimeler: Fekal diversiyon, Trefin stoma, sonuçlarımız

Key words: Fecal diversion, trephine stoma, outcomes

${ }^{1}$ Department of General Surgery, Dicle University Medical Faculty, Diyarbakır, Turkey

${ }^{2}$ Department of Radiation Oncology, Dicle University Medical Faculty, Diyarbakır, Turkey

Correspondence: Abdullah Oğuz, Department of General Surgery, Dicle University Medical Faculty, Diyarbakır, Turkey Email: dragtiz@hotmail.com Received: 08.03.2015, Accepted: 22.04.2015 Copyright @ JCEI / Journal of Clinical and Experimental Investigations 2015, All rights reserved 


\section{INTRODUCTION}

Stoma is an important part of surgical management of numerous malignant or benign anorectal diseases [1] and anorectal injuries [2-3]. Multiple techniques have been described for creation of colostomies and ileostomies over the last decades, but almost all of them have included an open laparotomy incision separate from the stoma site itself [4]. Trephine stoma (TS), which is a less invasive technique with less morbidity and mortality rate, was defined by Senapi firstly in 1991 as an end sigmoid colostomy and has recently been suggested to have advantages over more traditional techniques due to avoiding laparotomy [5].

TS provides numerous advantages for the patients without laparotomy indications. These advantages include less operation time, less postoperative pain, less ileus and wound site complications, less postoperative analgesic requirement, applicability under regional anesthesia, less duration of hospital stay and it provides the opportunity of starting early chemotherapy and radiotherapy if necessary $[6,7]$.

In this study, we carried out a retrospective assessment of the outcome of trephine colostomy in our own practice.

\section{METHODS}

The retrospective study included 14 patients who underwent TS due to various indications including Fournier's gangrene, inoperable anorectal cancer, recto-vaginal fistula, and benign stricture due to radiotherapy at Dicle University Medical School General Surgery Clinic between January 2010 and January 2015. Demographic characteristics, primary pathology for colostomy decision, length of hospital stay, anesthesia technique, and early period surgical complications at 3 months were recorded.

\section{TS operative technique}

The projected stoma site is marked before initiating the surgery. To achieve a standard stoma, a disk of skin and subcutaneous tissue is incised, which can be performed via the half of the rectus abdominis muscle on either side. An incision in a cruciate fashion is made on the anterior rectus fascia, an opening is made on the rectus abdominis muscle in parallel with its fibers, an incision is made on the posterior sheath, and an opening is made on the peritoneum. If necessary, the opening may be extended in vertical or horizontal directions. The pelvic colon is clutched and pulled into the wound by using two Babcock's tissue forceps. If needed, lateral mobilization can be performed with a short mesentery or some peritoneal adhesions by using scissors. Following the confirmation of orientation, a loop trephine sigmoid colostomy is constructed without necessitating laparotomy.

\section{RESULTS}

A total of 14 patients underwent TS surgery. The patients included 10 men and 4 women with a mean age of 52.07 (range, 32-81) years. In accordance with the aim of fecal diversion, loop trephine sigmoid colostomy (Figure 1) was performed in all the patients due to various indications including Fournier's gangrene in 7 cases, inoperable anorectal cancer in 5 cases, rectovaginal fistula in 1 case, and benign stricture due to radiotherapy in 1 case. Regional anesthesia was performed in 8 and general anesthesia in 6 cases. TS was applied under emergency conditions in 9 cases and under elective conditions in 5 cases. Mean hospital stay was 14 days. The temporary stomas were closed 3 months after first operation. One patient with permanent stoma underwent second operation at postoperative month 3 due to colostomy prolapse and the colostomy was reconstructed. There were no other complications and no additional morbidity and mortality related to TS technique.

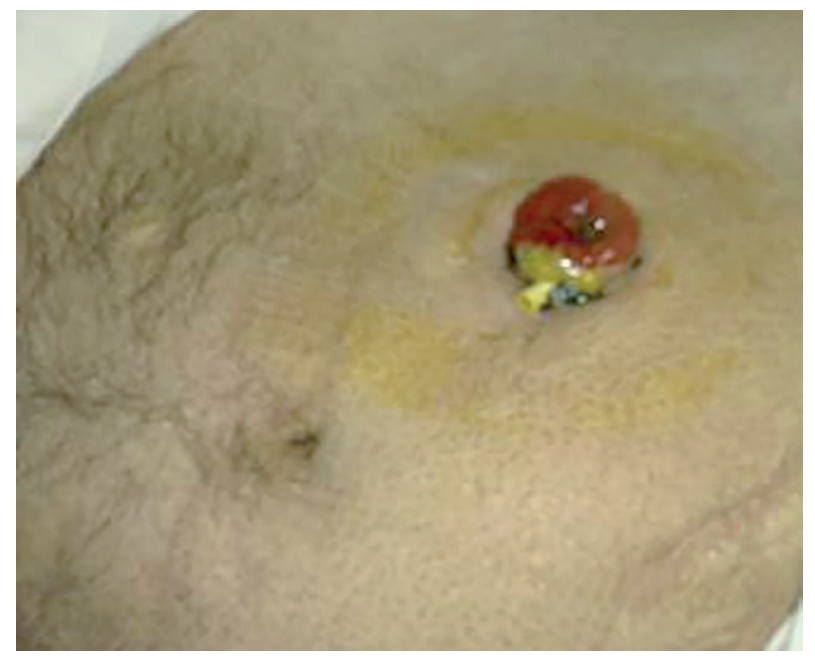

Figure 1. Postoperative appearance of Trephine ostomy

\section{DISCUSSION}

TS does not need a wide laparotomy incision and thus a minimal dissection is made [6]. TS is applicable in extensive indication area such as fecal 
incontinence, complex perianal sepsis, palliation for inoperable or locally recurrent ano-rectal carcinoma prior to a number of conditions including anal sphincter reconstructive surgery, sigmoid volvulus, rectourethral fistula, high fistula in ano- and rectovaginal fistula or neoadjuvant therapy for rectal cancer $[4,8,9]$. Senapati and Phillips reported that the indications in 16 patients included fistula-inano, constipation, incontinence, and anal pain [5]. Soyder et al. performed TS in 23 patients due to various indications including perineal sepsis, inoperable anorectal cancer, recto-vaginal fistula, fecal incontinence, and sigmoid volvulus [10]. Patel et al. performed TS in 31 patients due to palliation for inoperable or locally recurrent rectal carcinoma, anal carcinoma, high fistula in ano, inflammatory bowel disease, incontinence, and recto-vaginal fistula [8]. In our study, we performed TS due to Fournier's gangrene in 7 cases, inoperable anorectal cancer in 5 cases, high recto-vaginal fistula in 1 case, and benign stricture caused by radiotherapy in 1 case.

Trephine stoma technique can be applied as ileostomy or colostomy, end or loop $[5,10]$. Caruso et al. performed trephine end colostomy after rectal decompression due to sigmoid volvulus [11]. Senapati and Phillips et al. performed end sigmoid colostomy in 16 cases [5]. Nylund et al. used loop ileostomy in 7 cases and end sigmoid colostomy in 15 cases via TS out of 27 cases [6]. In our study, we performed loop sigmoid TS in all the patients.

In a study involving 27 patients, TS was successfully constructed in 22 patients and formal laparotomy was needed in five patients mainly because the sigmoid colon was immobile or there were extensive adhesions [6]. Patel et al. performed TS in 31 patients, and the laparotomies in 9 cases were constructed due to immobile sigmoid colon [8]. In our study, no laparotomy was needed.

Complications related to the stoma have been reported including retraction of the stoma, stricture of the stoma, prolapse of the stoma, parastomal hernia, and acute urinary retention [4-8]. In our study, only one patient had colostomy prolapse. Soyder et al. performed TS in 23 patients and one patient underwent second surgery due to colostomy descent [10]. Senapati and Phillips reported retraction in $13 \%$ of the patients [5]. Patel et al. reported that complications related to the stoma occurred in 12 patients. Of these, retraction of the stoma was the most frequently encountered problem occurring in 8 of the patients, followed by prolapse of the stoma in 2 patients and stricture of the stoma in one patient [8].

Previous abdominal surgery is no contraindication for TS [7]. Patel et al. reported that 4 out of the 7 patients with a previous laparotomy had a successful TS [8]. Stephenson et al. reported that stoma was created successfully in 12 patients who had previously undergone colorectal surgery [4]. In our series, no history of abdominal surgery was present in any patient.

Mean hospital stay after TS is reported between 9-11 days $[4,5,7,10]$. In our study, mean length of hospital stay was 14 days, but in $50 \%$ of the cases such as the ones with Fournier's gangrene, the operation was used as part of the management of other conditions which led to an increased length of stay in hospital.

TS is applicable under regional or general anesthesia, and also under emergency or elective conditions $[4,10]$. A significant advantage of the TS appeared to be the ability to perform surgery under regional anesthesia [4]. This may be very attractive in the patients with concurrent morbidities, especially pulmonary disease, in whom complications might be decreased by the avoidance of general endotracheal intubation [12], especially in mortal diseases like Fournier's gangrene [13]. In our study, TS was applied under emergency conditions in 9 cases and under elective conditions in 5 cases, and 8 [57\%] patients underwent surgery under regional anesthesia.

In conclusion, this study shows that creation of a trephine stoma is a relatively simple, safe and rapid procedure and may be an attractive alternative for those patients who require a stoma but not a laparotomy. It can be performed under emergency or elective conditions with low morbidity.

\section{REFERENCES}

1. Güenaga KF, Lustosa SA, Saad SS, et al. lleostomy or colostomy for temporary decompression of colorectal anastomosis. Systematic review and meta-analysis. Acta Cir Bras 2008;23:294-303.

2. Gümüş $M$, Kapan $M$, Önder $A$, et al. Factors affecting morbidity in penetrating rectal injuries: A civilian experience. Turk J Trauma Emerg Surg 2011;17:401-406.

3. Gümüş $M$, Böyük $A$, Kapan $M$, et al. Unusual extraperitoneal rectal injuries: a retrospective study. Eur J Trauma Emerg Surg 2012;38:295-299.

4. Stephenson ER Jr, Ilahi O, Koltun WA. Stoma creation through the stoma site: a rapid, safe technique. Dis Colon Rectum. 1997;40:112-115. 
5. Senapati A, Phillips RK. The trephine colostomy: a permanent left iliac fossa end colostomy without recourse to laparotomy. Ann R Coll Surg Engl 1991;73:305-306.

6. Nylund G, Oresland T, Hultén L. The trephine stoma: formation of a stoma without laparotomy. Eur J Surg 1997;163:627-629.

7. Anderson ID, Hill J, Vohra R, et al. An improved means of faecal diversion: the trephine stoma. $\mathrm{Br} \mathrm{J}$ Surg 1992;79:1080-1081.

8. Patel P, Wright A, Messersmith R, Palmer J. Does trephine colostomy produce a satisfactory stoma? Colorectal Dis 2001;3:270-271.

9. Carne PW, Frye JN, Robertson GM, Frizelle FA. Parastomal hernia following minimally invasive stoma formation. ANZ J Surg 2003;73:843-845.
10. Soyder A, Özgün H. Trephine ostomy: safe and simple. Surgery Curr Res 2013, 3:4 http://dx.doi. org/10.4172/2161-1076.1000139

11. Caruso DM, Kassir AA, Robles RA, et al. Use of trephine stoma in sigmoid volvulus. Dis Colon Rectum 1996;39:1222-1226.

12. Hendolin $H$, Lahtinen J, Länsimies $E$, et al. The effect of thoracic epidural analgesia on respiratory function after cholecystectomy. Acta Anaesthesiol Scand 1987; 31: 645-651.

13. Oguz A, Gümüş $M$, Turkoglu A, et al. Fournier's Gangrene: A summary of 10 years of clinical experience. Int Surg 2015 In-Press. doi: http://dx.doi.org/10.9738/ INTSURG-D-15-00036.1. 